\title{
Correction to: Building a trusted framework for uncertainty assessment in rare diseases: suggestions for improvement (Response to "TRUST4RD: tool for reducing uncertainties in the evidence generation for specialised treatments for rare diseases")
}

\author{
Sabine E. Grimm ${ }^{1 *}$, Xavier Pouwels², Bram L. T. Ramaekers', Ben Wijnen', Saskia Knies ${ }^{3}$, Janneke Grutters ${ }^{4}$ and \\ Manuela A. Joore
}

\section{Correction to: Orphanet J Rare Dis (2021) 16:62} https://doi.org/10.1186/s13023-020-01666-4

Following the publication of the original article [1] it was brought to our attention that some of the authors are part of the Evidence Review Group for the England \& Wales National Institute for Health and Care Excellence (NICE) and did not yet have permission to publish the case studies in this article, because final guidance has not been issued.

Any mentions to the case studies have, therefore, been removed from the original article, which has already been updated online.

\section{Author details}

'Department of Clinical Epidemiology and Medical Technology Assessment, School for Public Health and Primary Care (CAPHRI), Maastricht University
Medical Centre, P. Debyelaan 25, PO Box 5800, 6202 AZ Maastricht, Netherlands. ${ }^{2}$ University of Twente, Hallenweg 5, 7522 NH Enschede, Netherlands. ${ }^{3}$ Zorginstituut Nederland, Eekholt 4, 1112 XH Diemen, Netherlands. ${ }^{4}$ Department for Health Evidence, Radboud University Medical Centre, Post 133, PO Box 9101, 6500 HB Nijmegen, Netherlands.

Published online: 19 July 2021

Reference

1. Grimm, et al. Building a trusted framework for uncertainty assessment in rare diseases: suggestions for improvement (Response to "TRUST4RD: tool for reducing uncertainties in the evidence generation for specialised treatments for rare diseases"). Orphanet J Rare Dis. 2021;16:62. https://doi. org/10.1186/s13023-020-01666-4.

\section{Publisher's Note}

Springer Nature remains neutral with regard to jurisdictional claims in published maps and institutional affiliations.

The original article can be found online at https://doi.org/10.1186/s13023020-01666-4.

*Correspondence: Sabine.grimm@mumc.nl

${ }^{1}$ Department of Clinical Epidemiology and Medical Technology Assessment, School for Public Health and Primary Care (CAPHRI),

Maastricht University Medical Centre, P. Debyelaan 25, PO Box 5800, 6202

AZ Maastricht, Netherlands

Full list of author information is available at the end of the article

(c) The Author(s) 2021. Open Access This article is licensed under a Creative Commons Attribution 4.0 International License, which permits use, sharing, adaptation, distribution and reproduction in any medium or format, as long as you give appropriate credit to the original author(s) and the source, provide a link to the Creative Commons licence, and indicate if changes were made. The images or other third party material in this article are included in the article's Creative Commons licence, unless indicated otherwise in a credit line to the material. If material is not included in the article's Creative Commons licence and your intended use is not permitted by statutory regulation or exceeds the permitted use, you will need to obtain permission directly from the copyright holder. To view a copy of this licence, visit http://creativecommons.org/licenses/by/4.0/. The Creative Commons Public Domain Dedication waiver (http://creativeco mmons.org/publicdomain/zero/1.0/) applies to the data made available in this article, unless otherwise stated in a credit line to the data. 